\title{
Teachers' Need for Authentic Assessment to Assess Writing Skill at Grade VII of Junior High Schools in Teluk Kuantan
}

\author{
Refnaldi, M. Zaim, and Elva Moria \\ English Language Education \\ UniversitasNegeri Padang \\ Padang, Indonesia \\ refnaldi@yahoo.com, mzaim_unp@yahoo.com, and elvamoria77@gmail.com
}

\begin{abstract}
Authentic assessment is the process of gathering information by teachers about students' progress and achievement. It is done by using several activities that are relevant and closely related to daily life. The use of authentic assessment cannot be separated from teachers' need on it. This article aims to find out teachers' need on authentic assessment to assess writing skill of grade VIII students at junior high schools. This is a survey study. The data were collected through interview with 20 English teachers of junior high schools in TelukKuantan that teach grade VIII students. The interview was focused on the teachers' wants on authentic assessment for writing skill. The findings show that (1) there are several types of authentic assessment needed by the teachers; writing sample, process writing, portfolio, performance assessment, journal and project/exhibition; (2) the topics needed were factual and familiar topics for students such as family, famous people, things around them; and (3) teachers need simple analytical scoring rubrics. Clearly, the teachers need several types of authentic assessment that are appropriate to assess students' writing skill.
\end{abstract}

Writing Skill

Keywords-Authentic Assessment, Teachers' Needs,

\section{INTRODUCTION}

Assessment plays important roles in teaching and learning process $[1,2,3]$. It can be defined as a process to gather information about students' learning process [4]. Through assessment, teachers can determine students' success in learning. In addition, assessment can be a reflection of teachers' success in teaching. It serves as assistance for teachers in deploying the students into certain groups, improving teaching method and providing guidance [5]. Through a good assessment, teachers can get concrete data needed. In short, assessment is an integral component of any successful teaching effort $[6,7]$

However, assessment is commonly assumed as a test. Teachers use such kinds of test to gain students' information. For example, to gain students' performance in reading, teachers use paper test like multiple choices, cloze procedure, and essay. It seems that teachers assess their students only by using test. In fact, based on the literature assessment is not only about test. Test is one of the tools in assessing students.
In the past, assessment primarily seen as a means to determine, measures and thus for certification, and now a belief that the potential benefits of assessing are much wider and impinge on in all stage of the learning process [8]. In addition, traditional models of assessment can exacerbate the problem by delaying development of independent thinking [6]. However, there are many ways to assess students' performance instead of using such kinds of test or other traditional models of assessment. The need to contextualize assessment in interesting, real-life and authentic tasks is described as one of the crucial elements of alternative or competency-based assessment that suit current educational goals [8]. Thus, teachers have to have a good knowledge about assessment in order to gain concrete information about students learning process.

Nowadays, there is a term 'authentic assessment' that becomes popular. Increasing the authenticity of an assessment is expected and experience by students to have a positive influence on students learning and motivation $[9,10,11]$. This kind of assessment tends to assess students' performance in the real-life contextusing several activities [12, 13, 3].In other words, authentic assessment can be said as the way of teacher to evaluate students' knowledge and skill and encourage them to apply what they have been acquire in the real-life situation.

Furthermore, authentic assessment does not only use such kinds of test but also use some other criteria such as students' attitude, motivation, and performance to collect information. It is consist of several forms of assessments that reflect students learning process, achievements, motivation and attitude [14]. Briefly, authentic assessment is a kind of assessment that focuses not only on the skill or performance of the students but also about the ongoing process that students face to acquire the skill.

Moreover, there are several characteristics of authentic assessment. Authentic assessment intended for measuring knowledge and skills of students, assessing students' performance with relevant and contextual tasks and various ways and form of sources [15]. There are some characteristics of authentic assessment propose by Brown [10]: (1) require students to perform, create, produce or do something, (2) use 
real world context or simulations, (3), are non-intrusive in that they extended the day do day classroom activity, (4) allow students to be assessed on what they normally do in class every day, (5), Use task that represent meaningful instructional activities, (6) Focus on process as well as product, (7) tap into higher level thinking and problem solving skill, (8) provide information about strengths and weakness of students. Thus, authentic assessment can be one solution for assessing activities.

There are some types of authentic assessment. Brown [10] proposes six types of authentic assessment that can be used by teachers in assessing language. They are performancebased assessment, portfolios, journal, conferences and interview, observation, self-and peer- assessment. He called them as alternative assessment. Those assessments can be used to assess certain skill such as reading, writing, speaking and listening. O'Malley and Pierce [14] suggest teachers to choose appropriate types of authentic assessment which is meet their need in instruction. They are also suggested to be creative to serve their assessment more authentic. Thus, teachers need to have much knowledge about authentic assessment in order to us them appropriately.

In line with those types of authentic assessment above, there are several types of authentic assessment that suitable to assess writing skill. They are writing sample, project/exhibition, experiment or demonstration, constructed response items, portfolio, performance-based assessment, journal, self- and peer- assessment, and process writing. Those types of assessment can be selected by the teachers based on their need and also students' need.

Conducting need analysis on the assessment is something important to do. It examines what students know already and what they need to know. It can be done through interview, questionnaire and other ways to ask the information. As stated by Nation and Macalister [16], need analysis have various focuses, they are lack, want, and necessity. Moreover, Jordan [17], states some other terms have been proposed for need, they are: demands, likes, deficiencies, goals, aims, purpose and objective. The information might be about students, the subject, instruction, etc. and it might come from some sources. In addition, Richard [18] says that need analysis is procedures to collect information about learners' need and also teachers' need. It can be used to determine if an existing assessment adequately addresses the needs of potential students and to collect information about a particular problem learners are experiencing in doing the assessment. Clearly, need analysis should be conducted in developing authentic assessment.

Furthermore, Hutchinson and Waters in Nation and Macalister [16] divide needs into target needs and learning needs. For example in analyzing target need; what is necessary in the students' use of language? What do the students lack? What do the students wish to learn? Those can be implied that necessities fit into require knowledge, lacks fit into present knowledge, and wants fit into subjective needs.

Theoretically, need analysis is the most important point in developing authentic assessment. It examines what users know already and what they need. It can be done through interview, questionnaire and other ways to ask the information. Need analysis have various focuses, they are lacks, want, and necessity [16]. Moreover, Jordan [17] states that there are some other terms have been proposed for need, they are: demands, likes, deficiencies, goals, aims, purpose and objective. The information might be about students, the subject, instruction, etc. and it might come from some sources. Briefly the main point in this analysis is to pose some fundamental questions than will be guideline to make sure that a course is contain relevant and useful thing to learn and also to develop the appropriate instructional design.

Moreover, in analyzing the need of authentic assessment for authentic writing, some things to do are look atthe necessity, lack and want. Want is the focus of writer in this article. Teachers have their own view about what they think is useful for their students. The information gathered is important to consider whether the teachers' views and the need analyst's views are same or not. The information can be gotten through an interview or a questionnaire. However, questionnaires are quite difficult to design well. As stated by Nation and Macalister [16], questionnaires are notoriously difficult to design well, but a well-designed can be a very useful source of information. The questions involve what teachers think will improve their students' writing skill and what they want to be able to improve their writing assessment. Clearly, this point encourages the teachers to give their opinion about what they want and need on authentic assessment.

Furthermore, there are some studies regarding the use and the need of authentic assessment. First research was done by Zaim and Refnaldi [19], entitled teachers' need on authentic assessment for speaking skills. They found that teachers' needs for authentic assessment are in high and medium categories and the level of teachers' need on the forms of authentic assessment activities are varies.

Second research was done by Gullikers,Bastiaens, and Kirschner [11]. The title is 'Perception of Authentic Assessment'. This research aimed to prove how important the development and the use of authentic assessments are. They conducted a qualitative study to explore students' and teachers' perception about this issue. The finding of this research shows that authentic assessment is multi-faceted concept that appears to be important in education. Finally, the researchers suggested to the future researchers to discuss this issue before developing authentic assessments.

Third research was done by McCarthy [20]. The title is 'Authentic Assessment - Key to Learning'. It aimed to show how the use of authentic assessment can engage millennial students in the learning process. The finding shows that not only analytical and evaluation skill, but also self-assessment and self-reflection skills ensure that students will graduate as reflective practitioners, equipped for continuing professional development. In other words, authentic assessment encourages students to be ready in the real world situation. At last, the writer suggested using authentic assessment in learning. 
Fourth was research by Zaim [21] entitled 'Authentic Assessment: The Implementation and Problems in English Instruction at Junior High School. Beside to find out the implementation and the problem of authentic assessment in junior high school, this research also aims to see teachers' knowledge about authentic assessment. The finding of this research shows that teachers' knowledge about authentic assessment is good enough. However, the implementation is still not good. The researcher suggests the teachers to have training related to authentic assessment. In short, this research encourages the writer to make a model of authentic assessment to help junior high school teachers in implementing authentic assessment.

Several related studies above imply that there have been many researches among authentic assessment. They tried to show the important and benefits of authentic assessment. Meanwhile, only one research was done by Zaim and Refnaldi [19] that studied about the needs of teachers on authentic assessment. Ideally, teachers' needs on authentic assessment should be analyzed before they construct or conduct the assessment in the classroom. As noted by Gielen, Dochy and Dierick [8], the construction of tasks, the development of criteria for assessment and the scoring performance may be shared or negotiated among teachers and students. Supported by Lombardi [6], educators who strive to bring authentic learning experiences to their students have to devise appropriate and meaningful measures to assess students' learning and mastery of concepts at hand. Thus, in this article the writers try to analyze teachers' need on authentic assessment for writing skill. The discussion focuses on the needs of authentic assessment types, topics and scoring rubrics.

\section{METHOD}

This is a survey study. The data were collected through structured interview with 20 English teachers of junior high schools in TelukKuantan. They teach grade VIII students. The interview was focused on the teachers' wants on authentic assessment for assessing students' writing skill. They were categorized into types of authentic assessment needed, topics needed and scoring rubrics needed. The data were analyzed through quantitative and qualitative data analysis.

\section{RESULT AND FINDING}

The data about teachers' wants on authentic assessment were divided into several components. They were types of authentic assessment needed, topics needed, and scoring rubrics needed. The first component that had been analyzed is about types of authentic assessment needed. To know the needs on authentic assessment of the teachers, the writers did not directly ask about it. First, the teachers were asked to review their knowledge about authentic assessment and asked their opinion about. Most of the teachers said that authentic assessment is a form of assessment that consists of several forms of assignment. They also said that this assessment system is good for assessing junior high school students. Meanwhile, some of them said that authentic assessment is an assessment that related to daily life. Their statements were in line with the definition of authentic assessment stated by some experts. As stated by Schurr [12], authentic assessment is a type of evaluation that more realistic and relevant. In addition, O'Malley and Pierce [14] stated that authentic assessment consists of some forms of assessments. In short, both of the teachers know the basic of authentic assessment.

Second, the writers asked about their assessment activities; what kind of assignments they used especially for assessing students' writing skill. It was aimed to know whether the teachers have used authentic assessment or not. Then, most of the teachers stated that they used several kinds of writing test such as short essay, writing prompts, fill in the blank, sentence arrangement and portfolio. In addition, some of them stated that they have used journal in assessing students' writing skill. Regarding to the types of authentic assessment, only three of the assignments stated were classified as authentic assessment. According to some experts $[14,10]$, there are several types of authentic assessments, some of them are writing prompts, journal and portfolio. It can be implied that the teachers have used three types of authentic assessment. In fact, there are some other types of authentic assessment that can be used for assessing students writing skill such as project/exhibition, self-peer assessment, picture description, writing process and some others.

Furthermore, portfolio is a type of authentic assessment that can be used for assessing four English skills. Especially in assessing writing skill, this type of authentic assessment is really appropriate. As proven by Nezakatgoo [22] through his research. He did a research to analyze the effects of portfolio assessment on writing of EFL students. The results of the research revealed that students whose work was evaluated by a portfolio assessment had improved their writing and gained higher score in final examination when compared to those whose work was evaluated by traditional assessment. The findings of the present study prove that portfolio assessment is effective assessment that can be used on writing assessment system.

Third, the writers discussed with the teachers about types of authentic assessment that appropriate for assessing writing skill. The writers stated nine types of authentic assessment that appropriate for assessing writing skill. Those are proposed by O'Malley and Pierce and Brown. They are writing sample, project/exhibition, experiment or demonstration, constructed respond items, portfolio, performance assessment and writing process. Furthermore, more than half of the respondents stated four types of authentic assessment that appropriate for assessing grade VIII students' writing skill; writing sample, experiment or demonstration, portfolio, and performance assessment. Meanwhile, rest of them agree that grade VIII students' writing skill can be assessed using several types of authentic assessment such as writing sample, project/exhibition, experiment or demonstration, portfolio, performance assessment and journal. It can be concluded that most of the teachers agree that constructed respond item and self- peerassessment were not suitable for grade VIII students. 
To clarify some types stated by the teachers, the writers then asked them about the competencies or materials that can be assessed by using the authentic assessment. According to them, there are two main competencies taught at grade VIII; short monologue text and short functional text. Short monologue text consists of descriptive, recount and narrative text. Meanwhile, short functional text consists of short message, advertisement, announcement, invitation and notice. Thus, several types of authentic assessment that had been stated by the teachers were supposed to be used for assessing those materials.

At last, the writers asked about a model of authentic assessment that used by the teachers. In fact, more than half of the teachers stated that they do not have a model of authentic assessment. Therefore, the writers asked them about types of authentic assessment that they want for assessing grade VIII students' writing skill. One of the teacher stated that she want several types of authentic assessment; writing sample, experiment/demonstration, portfolio and performance assessment. According to her, writing sample and performance assessment can be used for assessing both short monologue text and short functional text; experiment/demonstration can be used for short functional text; and portfolio can be used for both short monologue text and functional text. Meanwhile another teacher said that she wants several types of authentic assessment; writing sample, project/exhibition, experiment/demonstration, portfolio, performance assessment, and journal. In short, the teachers need varied forms of assessment for assessing writing skill. The types of authentic assessment needed can be seen clearly in the table 1:

Table 1

Types of Authentic Assessment Needed

\begin{tabular}{|l|l|l|l|l|l|l|l|c|}
\hline \multirow{2}{*}{ No } & \multirow{2}{*}{$\begin{array}{c}\text { Types of } \\
\text { Authentic } \\
\text { Assessment }\end{array}$} & N I & $\begin{array}{c}\text { L } \\
\text { I }\end{array}$ & I & V I & T & A & C \\
\cline { 3 - 6 } & Writing sample & 0 & 0 & 18 & 56 & 74 & 3,7 & VI \\
\hline 2 & $\begin{array}{l}\text { Project/exhibitio } \\
\text { n }\end{array}$ & 0 & 0 & 30 & 40 & 70 & 3,5 & I \\
\hline 3 & $\begin{array}{l}\text { Experiment or } \\
\text { demonstration }\end{array}$ & 0 & 8 & 42 & 8 & 58 & 2,9 & I \\
\hline 4 & $\begin{array}{l}\text { Constructed } \\
\text { respond items }\end{array}$ & 8 & 18 & 9 & 0 & 35 & 1,75 & LI \\
\hline 5 & Portfolio & 0 & 0 & 30 & 40 & 70 & 3,5 & I \\
\hline 6 & $\begin{array}{l}\text { Performance } \\
\text { assessment }\end{array}$ & 0 & 0 & 39 & 28 & 67 & 3,35 & I \\
\hline 7 & Journal & 0 & 4 & 45 & 12 & 61 & 3,05 & I \\
\hline 8 & $\begin{array}{l}\text { Self- peer- } \\
\text { assessment }\end{array}$ & 2 & 28 & 9 & 0 & 39 & 1,95 & LI \\
\hline 9 & Writing Process & 0 & 0 & 42 & 24 & 66 & 3,3 & I \\
\hline
\end{tabular}

Notes:

VI: Very Important, I: Important, LI : Less Important, NI:Not Important,

T: Total, A:Average, C: Classification

The table 1 shows the teachers' needs on the types of authentic assessment for assessing students' writing skill. There is a type of authentic assessment in the category very important that is writing sample. Then, six types of authentic assessment are categorized as important types. They are project/exhibition, experiment/demonstration, portfolio, performance assessment, journal and writing process. However, constructed respond items and self- peerassessment are categorized as less important types for grade VIII students. Clearly, there are some types of authentic assessment that highly needed by junior high school teachers.

It can be concluded that there are five types of authentic assessment that mostly needed by the teachers; writing sample, experiment or demonstration, portfolio, performance assessment and writing process. Meanwhile, project/exhibition and journal are also needed by. On the other hand, there are two types of authentic assessment that stated not and less important by the teachers; constructed respond items and self- peer- assessment. In short, from the nine types of authentic assessment appropriate for assessing writing skill, seven of them are needed by the teachers for assessing grade VIII students' writing skill.

This finding is related to research that had been done by Zaim and Refnaldi [19]. One of the focuses in that research was analyzing junior high school teachers' needs on forms of assessment for assessing speaking skill. The result shows that teachers' need o the forms of authentic assessment activities are varies. It can be implied that there are many types of authentic assessment needed by junior high school teachers.

The second component is about the topics needed by the teachers in authentic assessment. Firstly, the writers asked the teachers about topics used in writing assessment. Some of the teachers said that she gave a topic to be written by students. On the other side, other teachers said that they often let the students determine the topic by themselves. In last, all of the teachers agree that they should provide familiar and interesting topics in order to encourage students' interest in writing.

Taking into account of the important of the topics in authentic assessment, the writers then asked the teachers about the topics that they want for assessing students' writing skill. Most of the teachers stated twelve topics that she need for assessing writing. The topics were classmate, family, self, school, historical places, famous people, artist, fairy tale, legend, personal experience, announcement and advertisement. Meanwhile, there was a topic which is news that also needed by some of the teachers. It can be concluded that, all topics needed by the teachers were closely related to the real life context and familiar with the teacher, thus they can classified as authentic topics. The topics needed can be seen in detail in the table 2 :

Table 2

The Topics Needed

\begin{tabular}{|c|c|c|c|c|c|c|c|c|}
\hline \multirow{2}{*}{ No } & \multirow{2}{*}{$\begin{array}{l}\text { Topics for } \\
\text { Authentic } \\
\text { Assessment }\end{array}$} & \multicolumn{4}{|c|}{ Response } & \multirow[b]{2}{*}{$\mathbf{T}$} & \multirow[b]{2}{*}{$\mathbf{A}$} & \multirow[b]{2}{*}{ C } \\
\hline & & N I & L I & I & V I & & & \\
\hline 1 & Classroom & 0 & 0 & 15 & 60 & 75 & 3,75 & VI \\
\hline 2 & Family & 0 & 0 & 30 & 40 & 70 & 3,5 & $\mathrm{I}$ \\
\hline 3 & Self & 0 & 0 & 51 & 12 & 63 & 3,15 & I \\
\hline
\end{tabular}


Table 2. Cont

\begin{tabular}{|c|l|c|c|c|c|c|r|c|}
\hline 4 & School & 0 & 0 & 42 & 24 & 66 & 3,3 & I \\
\hline 5 & Fruits & 10 & 16 & 6 & 0 & 32 & 1,6 & LI \\
\hline 6 & Flowers & 12 & 14 & 3 & 0 & 29 & 1,45 & NI \\
\hline 7 & $\begin{array}{l}\text { Historical } \\
\text { place }\end{array}$ & 2 & 26 & 15 & 0 & 43 & 2,15 & LI \\
\hline 8 & $\begin{array}{l}\text { Tourism } \\
\text { place }\end{array}$ & 8 & 18 & 9 & 0 & 35 & 1,75 & LI \\
\hline 9 & $\begin{array}{l}\text { Famous } \\
\text { people }\end{array}$ & 0 & 0 & 39 & 28 & 67 & 3,35 & I \\
\hline 10 & Artist & 0 & 10 & 39 & 8 & 57 & 2,85 & I \\
\hline 11 & Fairy tale & 0 & 2 & 30 & 36 & 68 & 3,4 & I \\
\hline 12 & Legend & 8 & 16 & 9 & 4 & 37 & 1,85 & LI \\
\hline 13 & Biography & 14 & 12 & 0 & 0 & 26 & 1,3 & NI \\
\hline 14 & Experience & 0 & 0 & 39 & 28 & 67 & 3,35 & I \\
\hline 15 & News & 4 & 20 & 18 & 0 & 42 & 2,1 & LI \\
\hline 16 & Pollution & 12 & 16 & 0 & 0 & 28 & 1,4 & NI \\
\hline 17 & $\begin{array}{l}\text { Global } \\
\text { warming }\end{array}$ & 12 & 14 & 0 & 0 & 26 & 1,3 & NI \\
\hline 18 & Earthquake & 10 & 14 & 9 & 0 & 33 & 1,65 & LI \\
\hline 19 & Recipe & 4 & 20 & 18 & 0 & 42 & 2,1 & LI \\
\hline 20 & $\begin{array}{l}\text { Advertisem } \\
\text { ent }\end{array}$ & 0 & 0 & 12 & 64 & 76 & 3,8 & VI \\
\hline 21 & $\begin{array}{l}\text { Announcem } \\
\text { ent }\end{array}$ & 0 & 0 & 15 & 60 & 75 & 3,75 & VI \\
\hline
\end{tabular}

Notes:

VI: Very Important, I: Important, LI : Less Important, NI:Not Important,

T: Total, A:Average, C: Classification

The table 2 above shows the teachers' need on topics for authentic assessment. There were twenty one topics provided by the writers. Teachers' responses were varied. As can be seen in the table, there are three topics that categorized as very important topics based. In addition, there are seven topics are classified as important topics. They are family, self, school, famous people, artist, fairy tale, and experience. However, there are some other topics that categorized as less important and not important topics by the teachers. Seven topics are classified as less important topics; fruits, historical place, tourism place, legend, news, earthquake, and recipe. Moreover, flower, biography, pollution, and global warming are in the not important categories. In short, there are three topics in very important category and seven topics in important category. It can be implied that those topics are needed by the teachers.

This result was quite similar with the research done by Zaim and Refnaldi [19]. In their research, one of the needs that had been analyzed was teachers' need on topics of authentic assessment. It found that teachers need varied topics for administering authentic assessment. Those findings are in line with experts' opinion about topics in authentic assessment. Authentic assessment should use real world context or simulation [10, 11]. On the other hand, McCharty [20] notes that the students should choose a topic by themselves that they feel passionate about. It means that the topic on authentic assessment should be real-life context in order to encourage the useful task that valuable and applicable in daily life and it is better for teachers to let their students choose the topic by themselves.

The last component that had been analyzed is scoring rubric. In assessing writing skill, teachers need clear scoring rubric. It can help teacher to be objective in scoring activities. It also needs to be explained to the students. The students should know the aspects that will be assessed. In addition, giving feedback to students is something important. Feedback is important to help students calibrate their own judgment and gain confidence in their self-assessment [20]. Timely constructed feedback to and from peers and lecturers helps keep people motivated and improves their self-awareness. Thus, teachers need to use and explain clear scoring rubrics and give feedback to the students.

Based on the interview result, it found that one of the teachers stated that scoring rubrics are not really important to be explained to the students. In fact, based on the characteristics of authentic assessment, scoring rubric is something important in authentic assessment in order to help both teachers and students. As stated by Guliekers at all [11], authentic assessment is an assessment system that fair and free from bias so it does not advantage or disadvantage any group of students. It can be implied that teachers need clear scoring rubrics.

Furthermore, there are two kinds of scoring rubrics that commonly used in writing assessment [14]. They are analytical scoring rubrics and holistic scoring rubrics. Before asking the teachers about scoring rubrics that they need, the writer gave brief explanation about. Based on the interview result, most of the teachers stated that they did not use certain scoring rubrics since they found them really complicated. Thus, they said that they need analytical scoring rubrics which are simple and easy to be implemented. The table 3 shows the responds of teachers about scoring rubrics:

Table 3

Types of Scoring Rubrics Needed

\begin{tabular}{|c|l|c|c|c|c|c|c|c|}
\hline \multirow{2}{*}{ No } & \multirow{2}{*}{$\begin{array}{l}\text { Types } \\
\text { ofScoring } \\
\text { Rubrics }\end{array}$} & $\mathbf{N}$ I & $\begin{array}{c}\text { L } \\
\text { I }\end{array}$ & $\mathbf{I}$ & $\mathbf{V}$ I & T & A & C \\
\hline 1 & $\begin{array}{l}\text { Holistic } \\
\text { scoring }\end{array}$ & 0 & 0 & 30 & 40 & 70 & 3,5 & I \\
\hline 2 & $\begin{array}{l}\text { Analytical } \\
\text { scoring }\end{array}$ & 0 & 0 & 21 & 52 & 73 & 3,65 & I \\
\hline 3 & Primary trait & 9 & 18 & 6 & 0 & 33 & 1,65 & LI \\
\hline 4 & $\begin{array}{l}\text { Multiple } \\
\text { traits }\end{array}$ & 8 & 18 & 9 & 0 & 35 & 1,75 & LI \\
\hline
\end{tabular}

Notes:

VI: Very Important, I: Important, LI : Less Important, NI:Not Important,

T: Total, A:Average, C: Classification 
The table above shows that analytical scoring rubric is sated very important that was proven by the average score 3,65. Meanwhile holistic scoring is categorized as important scoring rubric by the average 3,5. On the other hands, there are two scoring systems are in less important category. It can be concluded that analytical scoring rubric is needed by junior high school teachers in scoring students' authentic assessment.

The finding about scoring rubrics needed by the teacher is related to the research done by Silva [23]. Her research findings revealed that the analytical scoring rubric was highly reliable in measuring writing proficiency of foreign language learners. Furthermore, Andrade [24] also notes that if carefully designed, scoring rubrics helps students to understand the goal of an assignment and support teachers in unbiased grading, giving feedback and assigning more challenging work to students. The important of rubrics in enhancing students' ability in writing is also stressed by Jaidev [25] that stated knowledge of writing rubrics helps students become more accountable for their own writing and it allow them to gain a greater sense of ownership of what they have written. Briefly, well designed scoring rubrics and clear explanation for the students are important for both teachers and students in order to reach the objectives of assessment itself.

\section{CONCLUSION}

Using authentic assessment for assessing writing skill is something needed. Teachers need to master some aspects of authentic assessment such as characteristics, topics and scoring rubrics. They also should know several types of authentic assessment that can be used for assessing certain skill. Furthermore, to develop authentic assessment, teachers' need on authentic assessment should be analyzed. The needs of teachers can be classified and concluded into three points; (1) teachers need several types of authentic assessment; writing sample, process writing, portfolio, performance assessment, journal and project/exhibition; (2) teachers need factual and familiar topics in administering authentic assessment such as family, famous people, and things around them; and (3) teachers need simple analytical scoring rubrics. Clearly, the teachers need several types of authentic assessment that are appropriate to assess students' writing skill.

\section{Acknowledgment}

This article is written based on the developmental research on authentic assessment funded by Ministry of Research, Technology and Higher Education in 2017. The writers would like to express their sincere appreciation to the teachers and as participants of this research.

\section{References}

[1] Surgenor, Paul, "Role of assessment" Unpublished, 2010, retrieved from www. Ucd.ic/teaching on July 2016.

[2] Jabbarifar, Taghi, "The importance of assessment and evaluation in educational system," Proceedings of the $2^{\text {nd }}$ international conference of teaching and learning, University College, Malaysia: 2000.
[3] Wiggins, G, "What are some types of assessment?" unpublished, 2008,pp. 1. Retrieved from http://www/edutopia.org/assessment-guide-description on July 2016.

[4] Scholtz, Andrew, "An analysis of the impact of an authentic assessment strategy on student performance in a technology-mediated constructivist classroom: a study revisited," International Journal of Education and Developement using Information and Communication Technology Vol.3, pp. 1, 2007.

[5] Retnawati et al, "Vocational High School Teachers' Difficulties in Implementing the Assessment in Curriculum 2013 in Yogyakarta Province Indonesia," Yogyakarta: International Journal of Instruction. ISSN: 1694-609X, 2016.

[6] Lombardi, Marilyn M, 2008,"Making the Grade: the Role of Assessment in Authentic Learning," Unpublished. 2008.

[7] Finch, Andrew, "Bring Classroom-Based Assessment into the EFL Classroom," Republic of Korea: Kyngpook National University, 2012.

[8] Gielenet all, "Evaluating the Consequential Validity of New Modes of Assessment: the Influence of Assessment on Learning, Including pre-, post-, and true assessment effects," Belgium: University of Leuven, 2003.

[9] Herrington, Janice A. and Herrington, Anthony J, "Authentic Conditions for Authentic Assessment: Aligning Task and Assessment," Research and Development in Higher Education vol. 29, 2005.

[10] Brown, H. Douglas, "Language Assessment Principles and Classroom Practices (Second Edition)," New York: Pearson Education, Inc. 2004.

[11] Gulikers, Judith T.M, Bastiaens, Theo J. and Kirschner, Paul A,"Perception of Authentic Assessment: Five Dimension of Authenticity,'Educational Technology Research and Development. Netherlands, 2014.

[12] Schurr, L. Sandra, "Authentic assessment: professional reference for teacher," Journal Teaching at Middle School, unpublished, 2002.

[13] Stiggin, R.J, "Revializing Classroom Assessment: The Highest Instruction Priority,” Phi Delta Kappan, 1987.

[14] O’Malley, J. Michael and Lorraine Valdez Pierce, "Authentic Assessment for English Language Learners: Practical Approaches for Teacher,'New York: AddisonWesley Publishing Company, 1996.

[15] Imran, Syaiful, "Authentic Assessment," unpublished, 2012, retrieved from http://ipankreview.wordpress.com/ on July 2016.

[16]Nation, I.S.P. and Macalister, John, "Language Curriculum Design,”New York: Routledge, 2010.

[17] Jordan, R.R, "English for Academic Purposes: A Guide and Resource Book for Teachers," Cabridge: Cambridge University, 1997.

[18]Richards, Jack C, "Curriculum Development in Language Teaching," United Kingdom: 2001,.

[19]Zaim, M. and Refnaldi, "Teachers' need on authentic assessment for speaking skill,'Paper presented at 
International Seminar on Language and Arts.Padang: FBS UniversitasNegeri Padang, 2016.

[20] McCharty, Grace, "Authentic Assessment - Key to Learning,"University of Wolongong Australia: Faculty of Business-Papers, unpublished, 2013.

[21]Zaim, M, "Assessment Otentik: ImplementasidanPermasalahannyadalamPembelajaranBa hasaInggris di SekolahMenengah,"Paper presented at International Seminar on Language and Arts. Padang: FBS UniversitasNegeri Padang, 2013

[22] Nezakatgoo, Behzad, "The effect of portfolio assessment on writing of EFL students, Iran, 2011, retrieved on January 2017.
[23] Silva, de Redhika, " Rubrics for Assessment: Their Effects on ESL Students' Authentic Task Performance," Open University of Sri Lanka, CELC Symposium, 2007.

[24] Andrade, H.G,"Teaching with rubrics: College Teaching," 2005, unpublished, retrieved from http://www.uri.edu/assessment/uri/2005teachingwithrubr ics on March 2017

[25] Jaidev, R, "Rubric-Based Writing: Liberating Rather than Restricting in Many Context," ELTWO Online, retrieved on March 2017 from http://blog.nus.edu.sg/eltwo/2011/03/17/rubrics-basedwriting-liberating-rather-than-restricting- in-manycontext/ 